\title{
Metode Pelatihan dalam Industri Perbankan pada Masa Pandemi Covid-19
}

\author{
Saldhi Felix Wijaya1, Johnson Dongoran² \\ 1,2 Universitas Kristen Satya Wacana, Salatiga, Indonesia
}

Keywords:

Training

Method;

Covid-19

Pandemic;

Banking

\section{ABSTRACT}

Abstract: The existence of this pandemic has resulted in the banking industry in Indonesia having to use online employee training due to Covid-19. This study aims to design training methods in banking during the COVID-19 pandemic. This study uses a qualitative descriptive method and uses data from 2 respondents in Islamic and conventional banks who know about training during the Covid-19 pandemic. Sources of data used in this study are primary data and secondary data. Methods of data collection using questionnaires and interviews. The data analysis technique used descriptive analysis techniques. The results of this study are that during the Covid-19 pandemic, employee training must continue and companies can conduct online training during this pandemic, both for internal programs and external programs by using online learning methods using the zoom application and training through LMS (Learning). management system) is an effective and efficient system during the current covid pandemic and a questionnaire as a training evaluation.

Kata kunci: Metode Pelatihan; Pandemi Covid-19; Perbankan

\begin{abstract}
Abstrak: Adanya pandemi Covid-19 ini mengakibatkan industri perbankan di Indonesia harus melaksanakan pelatihan karyawan secara online. Penelitiaan ini bertujuan untuk merancang metode pelatihan dalam perbankan pada masa pandemi covid-19. Penelitian ini menggunakan metode deskriptif kualitatif dan menggunakan data 2 responden di bank Syariah dan konvensional yang mengetahui pelatihan selama pandemi Covid-19. Sumber data yang digunakan dalam penelitian ini adalah data primer dan data sekunder. Metode pengumpulan data menggunakan kuesioner dan wawancara. Teknik analisis data menggunakan teknik analisis deskriptif. Hasil penelitian ini adalah dalam kondisi pandemi Covid-19 ini, pelatihan karyawan harus tetap berjalan dan perusahaan dapat melakukan pelatihan secara online, baik untuk program internal maupun program eksternal dengan cara menggunakan metode pembelajaran daring menggunakan aplikasi zoom dan pelatihan melalui LMS (Learning management system) merupakan sistem yang efektif dan efisien serta kuesoner sebagai evaluasi pelatihan.
\end{abstract}

Alamat Korespondensi:

E-mail: felixsaldhi@gmail (Felix)

\section{Pendahuluan}

Munculnya virus baru yang menjangkiti dunia saat ini yaitu Coronaviruses (CoV). Organisasi internasional bidang kesehatan yaitu World Health Organization menyatakan bahwa Coronaviruses (Cov) dapat menjangkiti saluran nafas pada manusia (Muhyiddin, 2020; Nalini, 2021). Virus tersebut memiliki nama ilmiah COVID-19 (De Brouwer et al., 2020; Yuliana, 2020). Pandemi virus Corona bukan hanya sekadar bencana kesehatan. Virus yang dikenal sebagai Covid-19 ini telah menimbulkan kekacauan di sektor ekonomi (Fahriani, 2020; Susilo et al., 2020). Pemerintah Indonesia menerapkan pembatasan dengan kebijakan social distancing (jaga jarak sosial, menghindari kerumunan), physical distancing (jaga jarak antar orang minimal 1,8 meter) sejak awal Maret 2020 (Durnalı, 2020; Kartiko \& Rachmi, 2021; Siti Choiriyah dan Setyo Riyanto, 2020). Kebijakan ini diharapkan dapat mengurangi penyebaran virus corona. Dampak dari COVID-19 tidak hanya mengganggu sektor kesehatan Indonesia, tetapi juga menyerang sektor ekonomi yaitu perbankan. Perbankan merupakan industri transaksi uang tunai, kredit, dan transaksi keuangan lainnya. Industri perbankan sangat penting bagi

$\begin{array}{ll}\text { History: } & \\ \text { Received } & \text { : 04 Juni2021 } \\ \text { Revised } & \text { : 10 Juni } 2021 \\ \text { Accepted } & \text { : 13 Juli } 2021 \\ \text { Published } & \text { : 25 Juli } 2021\end{array}$

Publisher: Undiksha Press

Licensed: This work is licensed under a Creative Commons Attribution 3.0 License

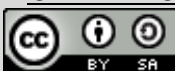


pembangunan perekonomian suatu negara. Pertama, perbankan sebagai penyedia mekanisme dan alat pembayaran yang efisien bagi nasabah. Kedua, perbankan menerima tabungan dari nasabah dan meminjamkannya untuk individu atau pihak yang sedang membutuhkan (Suranto \& Walandouw, 2017). Bila peran perbankan di atas berjalan dengan baik, maka secara otomatis perekonomian pun akan meningkat.

Namun kenyataannya, dalam situasi pandemi virus Covid-19, perusahaan di Indonesia harus tetap memperhatikan produktivitas karyawan meskipun harus bekerja dari rumah atau WFH (Kleo et al., 2020). Permasalahan lain, OJK melakukan penurunan batas minimum rasio LCR dan NSFR menjadi paling rendah $85 \%$ sampai dengan 31 Maret 2021. Selain itu, dilakukan penundaan pemberlakuan standar Basel III menjadi 1 Januari 2023. Bank Indonesia mengeluarkan kebijakan penurunan policy rate B17DRR turun dari $4.75 \%$ menjadi $4.00 \%$, penurunan GWM rate 200 Bps untuk BUK dan 50Bps untuk BUS/UU, dan pelonggaran Likuiditas di antaranya melalui pembelian SBN (Nasution et al., 2020). Hal ini dilakukan mengingat tidak seluruh sektor bisnis mengalami kerugian yang sama. Bahkan ada sektor tertentu yang mendapatkan keuntungan dari adanya pembatasan sosial. Oleh karena itu, diperlukan penghitungan berdasar sektor bisnis dan selanjutnya penghitungan masingmasing perusahaan (korporasi) (Hadiwardoyo, 2020). Ditahun 2020, perekonomian global tidak bisa diukur dengan hanya sebatas lingkup ekonomi itu sendiri. Virus Corona (Covid-19) menjadi bukti bahwa virus yang mengganggu kesehatan tersebut dapat menimbulkan ketidakstabilan ekonomi pada suatu negara bahkan dalam skala global (Burhanunddin \& Abdi, 2020; Laurensius Marshall Sautlan Sitanggang, 2020).

Kerugian ekonomi secara nasional akan memengaruhi APBN. Covid-19 memberikan dampak signifikan terhadap perkembangan ekonomi dunia. Pandemic Covid-19 adalah tantangan bagi dunia bisnis, termasuk industri jasa keuangan perbankan. Bank Syariah dalam menjalankan fungsinya sebagai lembaga intermediasi atau perantara keuangan yang mempertemukan antara masyarakat yang kelebihan dana dan masyarakat yang kekurangan dana dituntut untuk dapat berinteraksi dengan orang banyak. Namun di sisi lain, ancaman terhadap paparan virus Covid-19 menjadi tantangan bagi lembaga perbankan. Kondisi tersebut justru menjadikan ketahanan masyarakat mengalami kerentanan sosial. Kerentanan sosial membuat produktivitas menurun, mata pencarian terganggu, dan munculnya gangguan kecemasan sosial di masyarakat. Masalah penurunan produktivitas ini yang sangat mengkhawatirkan perusahaan karena dapat memengaruhi kinerja sumber daya manusia yang ada dalam perusahaan tersebut. Terlebih bagi perbankan yang memerlukan sumber daya untuk berbagai kegiatannya demi mencapai tujuan. Jika permasalahan tersebut dibiarkan, maka akan memberikan dampak negatif bagi perusahaan perbankan.

Solusi yang dapat diberikan yaitu karyawan dapat mengikuti berbagai pelatihan sebagai upaya meningkatkan kemampuan yang dimiliki selama pandemic covid-19. Pelatihan merupakan suatu kegiatan yang sangat dibutuhkan bagi setiap organisasi terutama dalam menghadapi perubahan-perubahan lingkungan bisnis yang terjadi dengan cepat (Efendi \& Winenriandhika, 2021; Suherman, 2018; Wijonarko et al., 2020). Cara tepat yang dapat dilakukan dalam upaya meningkatkan kinerja pegawai yaitu melalui pengembangan pegawai dengan melakukan pelatihan dan disiplin kerja. Dengan menerapkan sistem pelatihan online tersebut diharapkan karyawan dapat melaksanakan tugasnya dengan baik dan bertanggung jawab atas pekerjaan sehingga mampu meningkatkan kinerja karyawan (Efendi \& Winenriandhika, 2021; Suherman, 2018). Pentingnya kualitas karyawan dalam meningkatkan kinerja perusahaan, khususnya di bidang jasa perbankan, mendorong manajemen untuk selalu memberikan pembinaan dan pengembangan sumber daya manusia yang ada di perusahaan melalui pelatihan dan motivasi kerja kepada seluruh karyawan yang merupakan variabel utama dalam meningkatkan kualitas kinerjanya (Rachmawati, 2017; Rialmi \& Morsen, 2020; Siska, 2017). Pengembangan sumber daya manusia bertujuan untuk menghasilkan sumber daya yang handal dalam berorganisasi dan memiliki kompetensi yang sesuai dengan tujuan organisasi.

Metode pelatihan perbankan yang biasanya menggunakan metode offline, terutama pelatihan karyawan dalam rangka seleksi. Sekarang, dengan adanya pandemi ini mengakibatkan industri perbankan di Indonesia harus menggunakan pelatihan karyawan secara online (Prasetyo \& 
Gintoro, 2010; Wijonarko et al., 2020). Dalam rangka mencegah Covid-19, perbankan mewujudkannya dengan membentuk organisasi dengan pembelajar (learning organization) dan memanfaatkan pemahaman yang kuat pada penggunaan teknologi digital atau internet dengan penggunaan waktu dalam bekerja (time management) (Siti Choiriyah dan Setyo Riyanto, 2020). Pelatihan, seminar, dan workshop yang melibatkan karyawan dengan berbagai level dari jajaran direksi, anak perusahaan hingga karyawan baru untuk meningkatkan kemampuan soft skill dan hard skill karyawan setiap triwulan sekali. Program ini dilaksanakan dalam rangka meningkatkan kompetensi (knowledge, skill, dan attitude) dengan berbagai tahapan. Orientasi berprestasi dan nilai perusahaan bertujuan untuk memberikan pengetahuan dan keterampilan dalam mengelola, meningkatkan, dan mempertahankan motivasi yang tinggi, memberikan pemahaman terhadap nilainilai dan perilaku inti perusahaan, serta mempersiapkan mental sebagai seorang pekerja (Kleo et al., 2020). Human Resource memegang peranan penting dalam memastikan bahwa pengelolaan karyawan telah dilakukan dengan tepat dalam rangka memastikan produktivitas bisnis perusahaan tetap terjaga pada saat pandemi virus corona (Mandey \& Sahanggamu, 2014).

Beberapa penelitian membahas tentang metode pelatihan Prasetyo \& Gintoro, (2010). Sebagai alternatif dari pelatihan tradisional yang sudah berjalan sebelumnya, yaitu model pelatihan online berbasis web memberikan kemudahan bagi karyawan untuk mendapatkan pembelajaran melalui materi yang inovatif dan mudah dipelajari (Prasetyo \& Gintoro, 2010). Jenis aplikasi pembelajaran dalam jaringan (daring) pelatihan English for Academic Purposes (EAP) yang diterapkan oleh Pusat Layanan Bahasa Universitas PGRI Semarang pada masa pandemi COVID-19, peserta pelatihan mengalami beragam masalah, yaitu masalah teknis dan nonteknis. Pelatihan berpengaruh secara langsung dan signifikan terhadap kinerja karyawan PT Bank Riau Kepri. Hasil penelitian menunjukkan bahwa pelatihan berpengaruh signifikaan terhadap kinerja. Artinya, semakin baik pelatihan yang dilakukan, maka akan meningkatkan kinerja karyawan dan sebaliknya (Ningrum, 2013). Tujuan penelitian ini yaitu menganalisis metode pelatihan pada masa pandemi Covid-19, yaitu dengan metode online dengan mematuhi protokol kesehatan yang ada dengan efektif dan efisien.

\section{Metode}

Penelitian ini menggunakan metode deskriptif kualitatif yaitu mendeskripsikan atau menggambarkan metode pelatihan yang disusun oleh industri perbankan untuk menyesuaikan kondisi saat pandemi Covid-19. Subjek penelitian penelitian ini adalah Spoke manajer Bank Mandiri Tapen Semarang (Harun Sutopo) dan Operation manager Bank Muamalat Semarang (Edi Kristo). Kriteria pemilihan informan adalah pegawai yang mengelola atau mengetahui dalam pelaksanaan program pelatihan karyawan. Data yang dikumpulkan berupa data primer dan sekunder. Data primer adalah data yang diperoleh langsung dengan objek yang akan ditelitinya. Data sekunder adalah semua data yang diperoleh secara tidak langsung dari objek yang diteliti. Data sekunder dalam penelitian ini berupa beberapa jurnal dan buku. Metode pengumpulan data penelitian adalah wawancara langsung dengan informan. Wawancara dilakukan oleh 2 pihak yaitu pewawancara yang mengajukan pertanyaan dengan terwawancara yang memberikan data atas pertanyaan yang diajukan. Pedoman wawancara yang diberikan adalah 10 pertanyaan guna menjawab permasalahan penelitian tentang metode pelatihan yang digunakan perbankan selama masa pandemi Covid-19 ini. Setelah data yang diperlukan terkumpul melalui wawancara, lalu informasi dan keterangan yang ditemukan dalam penelitian ini menjadi data untuk dianalisiss dengan menggunakan metode deskriptif analisis. Deskriptif analisis merupakan metode analisis data yang memaparkan semua data diperoleh dari hasil wawancara, kemudian dianalisis sesuai dengan permasalahan dan tujuan penelitian yang selanjutnya akan disusun dalam bentuk laporan ilmiah. 


\section{Hasil dan Pembahasan}

Hasil

Berdasarkan hasil analisis data, Bank Mandiri sebagai organisasi yang dinamis selalu berinovasi dalam melakukan perbaikan secara berkelanjutan untuk mampu bertranfromasi dan mendorong mindset pegawai lebih terbuka dan terbiasa dengan perubahan. Di samping itu, Bank Mnadiri selalu berusaha mengadopsi best practices di bidangnya bahkan berinovasi melahirkan future practices. Dalam rangka pengembangan SDM, Bank Mandiri menerapkan empat strategi kunci terkini, yaitu dengan dorongan natural perseroan. Dengan demikian, SDM Bank Mandiri terbiasa menghadapi perubahan yang dimulai sejak perusahaan berdiri, disiplinnya perusahaan dalam melakukan dan menilai kinerja pegawai perusahaan, sehingga Bank Mandiri ketat dalam menerapkan sistem manajemen kualitas pegawai yang berbasis pada penilaian Key Performance Indicator (KPI). Hal tersebut diterapkan untuk mendorong pegawai Bank Mandiri supaya memiliki jiwa kompetisi tinggi dengan mengedepankan pembangunan fundamental bisnis yang semakin kokoh dengan sustainability yang terjaga dan mendorong terciptanya value creation. Penerapan budaya kerja yang konsisten dan berkelanjutan juga menjadi bagian dari strategi Bank Mandiri, sehingga tidak pernah kekurangan talenta terbaik dalam bekerja untuk mendorong pegawai Bank Mandiri selalu aktif dan responsif dalam menghadapi perubahan yang cepat terjadi dan kuatnya penerapan praktik tata kelola korporasi atau Good Corporate Governance (GCG) di seluruh lini kerja perseroan. Keempat hal itu juga menjadi dasar bank Mandiri untuk menjaga pengembangan bisnis secara berkelanjutan. Bank Mandiri menggunakan dan memanfaatkan teknologi yang ada untuk menerapkan sistem pelatihan yang tidak dapat ditunda terlalu lama karena dapat memengaruhi kinerja karyawan nantinya.

Tujuan program ini diharapkan mampu meningkatkan kompetensi dan pengelolaan waktu bekerja secara efektif dan efisien untuk menciptakan sumber daya manusia yang unggul dan berdaya saing selama pandemi Covid-19. Tahap pelaksanaan program melalui grup whatsapp, peserta masuk ke dalam grup whatsapp yang sudah diatur sesuai dengan kebutuhan setiap peserta. Di grup whatsapp ini nantinya peserta akan mendapatkan informasi-informasi terkait dengan pelatihan. Informasi tersebut memuat jadwal pelatihan yang akan dilaksanakan melalui aplikasi zoom. Materi yang akan dibahas melalui zoom akan diinformasikan terlebih dahulu melalui grup tersebut. Link juga dibagikan di grup ini melalui fitur deskripsi yang ada di aplikasi whatsapp. Pada tahapan ini virtual learning dilaksanakan menggunakan aplikasi zoom cloud meeting. Peserta berjumlah 30-200 karyawan, termasuk instruktur dan observer. Metode penyampaian materi yang digunakan adalah dengan contruktive learning. Penyampaian materi oleh instruktur melalui virtual kelas menggunakan zoom cloud meeting dalam waktu 3-5 jam.

Dengan case study and simulation, peserta diberikan simulasi yang sesuai dengan lingkungan kerja peserta dan dalam suatu kasus tertentu peserta harus melakukan pekerjaan/aktivitas sesuai intruksi dari intstuktur yang tentunya bertujuan untuk menyelesaikan kasus. Group Discussion yaitu peserta dikelompokkan untuk mendiskusikan suatu topik permasalahan yang dipandu oleh intstruktur. Pengelompokkan ini dialihkan pada fitur break out yang disediakan oleh aplikasi Zoom. Direct Coaching bertujuan untuk mengetahui pelanggaran-pelanggaran yang terjadi dan membuat ketidakefektifan yang dilakukan peserta pada saat program pelatihan. Metode ini dapat disampaikan intruktur pada saat itu juga agar program pelatihan dapat berjalan dengan baik. Dengan Assigment Learning Project yaitu pelatihan dilakukan dengan mengevaluasi pemahaman materi yang diberikan sebelumnya. Sistem evaluasi melalui kuesioner dengan menggunakan google form yang didalamnya terdapat 10 pertanyaan pilihan ganda. Setelah selesai mengerjakan tugas melaui google form, peserta langsung mendapat nilai sesuai yang dikerjakan pesert. Peserta minimal harus mendapatkan nilai 80 . Apabila ada peserta yang mendapatkan nilai kurang dari 80 , maka peserta harus mengulang mengerjakan atau bisa dikatakan remidi.

Pemilihan aplikasi zoom pada pelatihan karyawan efektif dan efisien karena beberapa hal Zoom memiliki harga yang murah dibandingkan dengan apalikasi pembelajaran yang berbasis web lainnya. Zoom memiliki tingkat delay yang rendah dalam menghantarkan suara dan gambar. Zoom juga dapat diakses dimana saja dengan menggunakan laptop maupun smartphone, tentunya dengan 
memastikan kestabilan jaringan internet. Selain itu, Zoom mudah digunakan siapa saja dengan fiturfitur yang dapat mengoptimalkan program pelatihan dengan mudah digunakan selama pelatihan berlangsung. Zoom dapat membuat pelatihan berskala besar menjadi mudah. Intsruktur dan peserta dapat dengan mudah beradaptasi. Peserta dapat mengikuti berbagai webinar-webinar yang diselenggarakan berbagai lembaga pelatihan, sehingga peserta diberi kebebasan untuk menambah pengetahuan. Peserta tidak hanya mengikuti pelatihan yang diselengggarakan perusahaan, tetapi dapat mengikuti webinar lain asalkan berhubungan dengan pekerjaan.

Program pelatihan Bank Muamalat selama Covid-19 ini menggunakan sistem daring. Sebelum dilakukannya program pelatihan yaitu tahap perencanaan pelatihan, pada tahap perencanaan ini dilaksanakan oleh HRD yang memegang peran yang sangat penting dalam pelatihan tersebut yang bertugas untuk menginput komponen-komponen apa saja yang diperlukan dalam pelatihan, antara lain, jadwal, peserta, materi pelatihan, metode, instruktur dan fasilitas pelatihan. Tahap perencanaan dilakukan dengan menentukan jadwal pelaksanaan pelatihan. Jadwal pelaksaan pelatihan, HRD mempertimbangkan waktu operasional. Hal Ini dilakukan bertujuan agar program pelatihan ini terlaksana dengan tidak mengganggu operasional Bank Muamalat. Oleh karena itu, HRD berkewajiban untuk mengatur jadwal agar tidak tabrakan antara jadwal pelaksanaan pelatihan dan lingkup pekerjaan yang sama. Pembagian tersebut akan dibuat beberapa batch agar karyawan yang memipunyai lingkup pekerjaan yang sama bisa mem-back up pekerjaan mereka yang sedang mengikuti program pelatihan

Peserta pelatihan memilih jenis pelatihan yang akan diikuti. Penyesuaian antara target peserta pelatihan dan jenis pelatihan bertujuan agar program pelatihan dapat berjalan sesuai dengan sasaran. Materi yang diberikan dalam pelatihan sesuai dengan job desk karyawan. HRD dalam menentukan dan memilih calon intruktur sangat mempertimbangkan latar belakang instruktur. Hal ini bertujuan agar nantinya intruktur yang memimpin pelatihan tersebut dan memberikan pelatihan dengan baik, sehingga terjadi kesesuaian antara wawasan atau pengetahuan yang dimiliki intruktur dan tema yang akan diberikan. Instruktur memilih atau menentukan materi didasarkan pada kebutuhan setiap peserta pelatihan agar kinerja karyawan dapat maksimal dan mewujudkan sumber daya manusia yang unggul dan berdaya saing. Ketika mengikuti program pelatihan selama masa pandemi Covid-19 ini, karyawan menggunakan handphone atau laptop milik pribadi agar dapat mengakses program pelatihan secara daring. Karyawan juga mendapatkan fasilitis e-sertifikat sesudah mengikuti program pelatihan sebagai bukti keikutsertaannya telah mengikuti program pelatihan,

Tahap pelaksanaan pelatihan, materi yang diberikan Bank Muamalat dalam pelatihan bertemakan antara lain, Effective Phone Selling Skill, Daily Productivity, Project Management. Program ini bertujuan agar karyawan Customer Service, RM Funding, Sub Branch Manager dapat berkerja secara maksimal walaupun harus Work from Home atau bekerja dari rumah selama pandemi Covid-19 ini. Menurut infoman, beberapa tema di atas sudah sesuai dengan kebutuhan karyawan masing-rmasing untuk meningkatkan kinerja karyawan selama pandemic Covid-19 ini. Program pelatihan diselenggarakan dengan materi yang bertujuan untuk meningkatkan kinerja dan menyelesaikan masalah karyawan di lapangan. Metode yang digunakan yaitu Learning Management System dan pembelajaran jarak jauh dengan menggunakan Zoom Cloud Meeting. Peserta pelatihan harus memiliki akun dan melakukan login agar dapat login ke dalam portal. Intruktur memberikan jadwal atau silabus selama masa pelatihan yang terstruktur. Untuk mengikuti webinar, peserta dapat undangan via Zoom yang juga tersedia dalam portal tersebut. Jadi, peserta dapat mengakses link Zoom melalui portal tersebut. Portal juga menampilkan total tugas yang diberikan intruktur kepada peserta dan juga pemberitahuan tugas yang belum dikerjakan pada saat peserta membuka portal tersebut. Materi yang akan dibahas dalam Zoom, sebelumnya sudah dikirim dalam portal tersebut dan peserta dapat mengakses dan mempelajari materi tersebut sebelum Zoom Meeting dimulai. Daftar kehadiran dan absensi portal ini juga secara otomatis mencatat data peserta yang berpartisipasi dalam pelatihan tersebut. Kuis diberikan melalui platform prospark setelah pelatihan terlaksana dengan sistem grading yang otomatis keluar setelah selesai menjawab pertanyaan. 
Evaluasi selama pelatihan diberikan setelah program pelatihan selesai dengan menggunakan link google docs. Peserta mengisi link tersebut untuk menilai kepuasan program pelatihan terkait dengan intruktur dan materi yang diberikan saat pelatihan. Melalui link google docs inilah HRD perusahaan dapat mengetahui reaksi peserta pelatihan setelah mengikuti program pelatihan. Program ini efektif dan efisien dikarenakan kinerja karyawan meningkat dan pengetahuan yang diberikan saat program pelatihan dilaksanakan sesuai job desk mereka masing masing. Program pelatihan ini juga menghemat anggaran pelatihan. Jadi, program pelatihan dengan metode ini dapat digunakan dimasa new normal sesuai dengan kebijakan pemerintah.

\section{Pembahasan}

Berdasarkan keseluruhan analisis deskriptif, maka diperoleh hasil penelitian sebagai berikut. Terdapat dampak metode pelatihan pada Bank Muamalat dan Bank Mandiri yang sebelumnya dilakukan secara offline. Selama pandemi covid-19 ini terpaksa digunakan metode pelatihan yang dilakukan secara daring dengan work from home. Pandemi ini menjadi tantangan baru bagi Human Resource dikarenakan program pelatihan terganggu dan tertunda. Work from Home dilakukan sesuai kebijakan dari pemerintah. Dengan adanya kebijakan ini, perusahan perbankan harus menerapkan sistem daring dalam melaksanakan program pelatihan untuk tetap menciptakan sumber daya manusia yang berdaya saing selama pandemi ini berlangsung. Jadi, perusahaan harus menyesuaikan kondisi saat ini dengan kontinyu dan dinamis. Di tengah pandemi Covid-19, pelatihan juga dapat dilaksanakan berdasarkan desain pelatihan dengan menyesuaikan waktu dan teknis tententu dengan membawa perubahan yang positif di tengah situasi pandemi (Siti Choiriyah dan Setyo Riyanto, 2020). Desain pelatihan yang digunakan di masa pandemi Covid-19 harus dipikirkan dengan sebaik mungkin, sehingga pelatihan yang dilakukan dapat terarah dan terencana sesuai dengan tujuan yang diharapkan agar bisa tercapai (Mustopa, 2020).

Kedua Bank menggunakan aplikasi zoom sebagai solusi dalam program pelatihan karena efektif dan efisien digunakan selama pandemi covid-19 ini. Menurut survey yang dilakukan melalui google form kepada karyawan, penggunaan aplikasi zoom sudah efektif karena mampu meningkatkan pengetahuan tentang pelatihan terumata tentang job desk masing masing karyawan. Penggunaan zoom dapat dikatakan efektif sebagai solusi selama pandemi ini karena dapat berinteraksi langsung antara intruktur dan peserta pelatihan. Selain aplikasi zoom, aplikasi lain seperti Learning Management System. Penggunaan aplikasi Learning Management System yang digunakan Bank Muamalat melalui platform ProSpark sangat bermanfaat selama pandemi ini sebagai media pembelajaran online terkait dengan work from home yang dijalani oleh karyawan. Aplikasi ini dapat mempermudah memanajemen dan memonitor karyawan dari awal sampai akhir pelatihan dilaksanakan. Aplikasi LMS ini, sistem pembelajaran dan komunikasi tetap berjalan dengan baik dengan memanfaatkan fasilitas yang tersedia dalam aplikasi LMS tersebut (Alfina, 2020; Fitriani, 2020; Prayogo, 2020). Manfaat yang diperoleh dengan adanya pengembangan berbagai fitur manajemen karyawan pada aplikasi LMS adalah melakukan evaluasi terhadap karyawan yang sedang dilatih dan mempermudah manajemen karyawan oleh pihak yang berwenang (Prayogo, 2020).

Pelatihan secara online ini dinilai mampu menjadi metode yang efektif dan efektif selama pandemi ini. Perusahaan harus tetap mengembangkan terus menerus pelatihan ini disesuaikan dengan perkembangan teknologi yang sangat pesat. Perusahaan juga harus memerhatikan unsur kreativitas dan interaktif peserta pelatihan selama pelatihan online ini dilaksanakan. Temuan penelitian ini diperkuat dengan penelitian sebelumnya bahwa pembelajaran daring sebagai tantangan pemimpin digital pendidikan tinggi abad 21 terbukti efektif dilaksanakan pada masa WFH akibat pandemic covid-19 (Darmalaksana et al., 2020). Pentingnya kualitas karyawan dalam meningkatkan kinerja perusahaan, khususnya di bidang jasa perbankan mendorong manajemen agar selalu memberikan pembinaan dan pengembangan sumber daya manusia yang ada di perusahaan melalui pelatihan dan motivasi kerja kepada seluruh karyawan. Karyawanmerupakan variabel utama dalam meningkatkan kualitas kinerjanya (Rachmawati, 2017). Berdasarkan pembahasan, penelitian ini mampu menerapkan hal baru dalam metode pelatihan karyawan secara daring. Diharapkan agar 
perusahaan tetap dapat menjalankan metode pelatihan bagi karyawan dalam bentuk online selama pandemi covid-19.

\section{Simpulan}

Metode pelatihan yang digunakan dalam industri perbankan, yaitu di Bank Muamalat dan Bank Mandiri di Semarang menggunakan metode pembelajaran daring dengan aplikasi zoom dan kuisoner sebagai evaluasi pelatihan yang sudah dilakukan. Pelatihan secara daring merupakan sistem yang efektif dan efisien selama masa pandemi Covid-19 ini. Program pelatihan melalui LMS (Learning management system) ini digunakan karena dapat lebih mudah memonitor perkembangan kinerja karyawan. Direkomendasikan agar perusahaan dapat mengadakan pelatihan secara offline apabila pelatihan secara online tidak memungkinkan dalam mengembangkan kinerja karyawan, tentunya dengan mengikuti protokol kesehatan yang ada seperti menjaga jarak, menggunakan masker, dan membawa hand sanitizer serta menyediakan fasilitas jaringan internet agar meminimalkan gangguan jaringan internet. Perusahaan juga harus konsisten dalam menjalankan program pelatihan untuk karyawan dalam masa pandemi Covid-19 ini dengan menyesuaikan kondisi dan perkembangan situasi yang ada.

\section{Daftar Pustaka}

Alfina, O. (2020). Penerapan Lms-Google Classroom dalam Pembelajaran Daring selama Pandemi Covid-19. Majalah Ilmiah METHODA, 10(1), 38-46. https://doi.org/10.46880/methoda.v10i1.537.

Burhanunddin, C. I., \& Abdi, M. N. (2020). Ancaman Krisis Ekonomi Global dari Dampak Penyebaran Virus Corona (Covid-19). AkMen2, 17(1), 90-98. https://e-jurnal.stienobelindonesia.ac.id/index.php/akmen/article/view/866.

Darmalaksana, W., Hambali, R. Y. A., Masrur, A., \& Muhlas. (2020). Analisis Pembelajaran Online Masa WFH Pandemic Covid-19 sebagai Tantangan Pemimpin Digital Abad 21. Karya Tulis Ilmiah (KTI) Masa Work From Home (WFH) Covid-19 UIN Sunan Gunung Djati Bandung Tahun 2020, 1(1), 1-12. http://digilib.uinsgd.ac.id/id/eprint/30434.

De Brouwer, E., Raimondi, D., \& Moreau, Y. (2020). Modeling the COVID-19 Outbreaks and the Effectiveness of the Containment Measures Adopted across Countries. MedRxiv, 3, 1-9. https://doi.org/10.1101/2020.04.02.20046375.

Durnalı, M. (2020). The Effect ofSself-Directed Learning on the Relationship between Self-Leadership and Online Learning among University Students in Turkey. Tuning Journal for Higher Education, 8(1), 129-165. https://doi.org/10.18543/TJHE.

Efendi, S., \& Winenriandhika, O. (2021). Pengaruh Rekrutmen, Pelatihan dan Pengalaman Kerja terhadap Kepuasan Kerja dan Dampaknya pada Kinerja Karyawan di PT Marketama Indah. Jurnal Ilmiah Nasional, 3(1), 99-110. https://doi.org/10.110915/jin.v3i1.383.

Fahriani, D. (2020). Dampak Virus Covid-19 bagi Perekonomian. 21(1), 1-9. https://doi.org/10.1016/j.solener.2019.02.027.

Fitriani, Y. (2020). Analisis Pemanfaatan Learning Management System (Lms) sebagai Media Pembelajaran Online selama Pandemi Covid-19. Journal of Information System, Informatics and Computing, 4(2), 1. https://doi.org/10.52362/jisicom.v4i2.312.

Hadiwardoyo, W. (2020). Kerugian Ekonomi Nasional Akibat Pandemi COVID-19. Journal of Business and Entrepreneurship, 2(2), 83-92. https://doi.org/10.24853/baskara.2.2.83-92.

Kartiko, N. D., \& Rachmi, I. F. (2021). Strategi Pemulihan Pandemi Covid-19 bagi Sektor UMKM di Indonesia. Jurnal Syntax Transformation, 2(5), 624-637. https://doi.org/10.46799/jurnal\%20syntax\%20transformation.v2i5.275.

Kleo, D. I. M. P., Ekonomi, F., \& Lampung, U. B. (2020). Asissten Deputy General Manager. 19.

Laurensius Marshall Sautlan Sitanggang. (2020). Jaga kinerja, Bank-Bank Getol Melakukan Efisiensi. Kontan.Co.Id.

Mandey, S., \& Sahangggamu, P. (2014). Pengaruh Pelatihan Kerja, Motivasi, dan Disiplin Kerja 
terhadap Kinerja Karyawan pada PT Bank Perkreditan Rakyat Dana Raya. Jurnal Riset Ekonomi, Manajemen, Bisnis Dan Akuntansi, 2(4), 514-523. https://doi.org/10.35794/emba.v2i4.6359.

Muhyiddin. (2020). Covid-19, New Normal dan Perencanaan Pembangunan di Indonesia. Jurnal Perencanaan Pembangunan: The Indonesian Journal of Development Planning, 4(2), 240-252. https://doi.org/10.36574/jpp.v4i2.118.

Mustopa, R. (2020). Pelatihan dan Pengembangan Manajemen Daya Manusia di Masa Pandemi $\begin{array}{lllll}\text { Covid-19. Jurnal Sosial Dan Teknologi } & \end{array}$ https://sostech.greenvest.co.id/index.php/sostech/article/view/21.

Nalini, S. N. L. (2021). Dampak Covid-19 terhadap Usaha Mlkro, Kecil, dan Menengah. Jesya (Jurnal Ekonomi \& Ekonomi Syariah), 4(1), 662-669. https://doi.org/10.36778/jesya.v4i1.278.

Nasution, D. A. D., Erlina, E., \& Muda, I. (2020). Dampak Pandemi COVID-19 terhadap Perekonomian Indonesia. Jurnal Benefita, 5(2), 212. https://doi.org/10.22216/jbe.v5i2.5313.

Ningrum, W. (2013). Pengaruh Pendidikan dan Pelatihan terhadap Kinerja Karyawan (Studi pada Karyawan Joint Operating Body Pertamina-PertoChina East Java). Jurnal Administrasi Bisnis S1 $\begin{array}{lll}\text { Universitas } \quad \text { Brawijaya, } & 78181 .\end{array}$ http://administrasibisnis.studentjournal.ub.ac.id/index.php/jab/article/view/303/495.

Prasetyo, T. I., \& Gintoro, G. (2010). Pengembangan Model Pelatihan Online Berbasis Web untuk Keunggulan Bersaing pada PT Intellisys Tripratama. CommIT (Communication and Information Technology) Journal, 4(2), 109. https://doi.org/10.21512/commit.v4i2.544.

Prayogo, R. (2020). Pengembangan Fitur Manajemen dan Evaluasi Karyawan pada Aplikasi Learning Management System Menggunakan Kerangka Kerja Laravel Jl . Palmerah Barat No . 48, Palmerah , Jakarta Barat, DKI Jakarta Periode : 22 Juni 2020 - 22 Juli 2020.

Rachmawati, R. W. (2017). Pengaruh Pelatihan Dan Motivasi Kerja terhadap Kinerja Karyawan PT Bank Bjb Kantor Cabang Suci Bandung. Jurnal Manajemen Dan Pemasaran Jasa, 9(1), 1. https://doi.org/10.25105/jmpj.v9i1.802.

Rialmi, Z., \& Morsen, M. (2020). Pengaruh Komunikasi terhadap Kinerja Karyawan PT Utama Metal Abadi. JENIUS (Jurnal Ilmiah Manajemen Sumber Daya Manusia), 3(2), 221-227. https://doi.org/10.32493/JJSDM.v3i2.3940.

Siska, A. J. (2017). Pengaruh Disiplin dan Motivasi Kerja terhadap Kinerja Guru pada SMAN 1 Canduang Kabupaten Agam. JUSIE (Jurnal Sosial Dan IImu Ekonomi), 1(02), 98-103. https://doi.org/10.36665/jusie.v1i02.139.

Siti Choiriyah dan Setyo Riyanto. (2020). Desain Pelatihan pada Masa Pendemi Covid-19 (Studi Kasus Penerapan Metode Constructive Learning pada Penyampaian Pembelajaran Virtual Learning). Journal of Chemical Information and Modeling, 21(1), 1-9. https://doi.org/10.36418/syntaxidea.v2i8`.371.

Suherman, U. D. (2018). Pengaruh Pendidikan dan Pelatihan terhadap Kinerja Karyawan BNI Syariah Cabang Bandung. JISPO Jurnal IImu Sosial Dan IImu Politik, 6(2), 1-8. http://journal.uinsgd.ac.id/index.php/jispo/article/view/3799.

Suranto, V., \& Walandouw, S. (2017). Analisis Pengaruh Struktur Modal dan Kinerja Keuangan terhadap Nilai Perusahaan pada Perusahaan Perbankan di Bursa Efek Indonesia. Jurnal EMBA: Jurnal Riset Ekonomi, Manajemen, Bisnis Dan Akuntansi, 5(2), 1031-1040. https://doi.org/10.35794/emba.v5i2.16059.

Susilo, A., Rumende, C. M., Pitoyo, C. W., Santoso, W. D., Yulianti, M., Herikurniawan, H., Sinto, R., Singh, G., Nainggolan, L., Nelwan, E. J., Chen, L. K., Widhani, A., Wijaya, E., Wicaksana, B., Maksum, M., Annisa, F., Jasirwan, C. O. M., \& Yunihastuti, E. (2020). Coronavirus Disease 2019: Tinjauan Literatur Terkini. Jurnal Penyakit Dalam Indonesia, 7(1), 45. https://doi.org/10.7454/jpdi.v7i1.415.

Wijonarko, G., Aribowo, H., Winarto, A., \& Ramadoni, W. (2020). Perancangan Program Pelatihan Karyawan dalam Rangka Mendukung Produktivitas. Jurnal EKSEKUTIF, 17(1), 35-46. https://jurnal.ibmt.ac.id/index.php/jeksekutif/article/view/254.

Yuliana. (2020). Corona virus diseases (Covid 19). Wellness and Healthy Magazine, 2(1), 187-192. https://doi.org/10.30604/well.95212020. 